\title{
Pembelajaran diskursus multi representasi terhadap peningkatan kemampuan komunikasi dan disposisi matematis mahasiswa
}

\author{
Ratni Purwasih $^{1}$, Martin Bernad ${ }^{1}$ \\ ${ }^{1}$ Jurusan Pendidikan Matematika, Institut Keguruan dan Ilmu Pendidikan (IKIP) Siliwangi. \\ Jalan Terusan Jenderal Sudirman, Cimahi 40526, Indonesia \\ * Corresponding Author. Email: ratnipurwasih61@gmail.com
}

Received: 8April 2017; Revised:10 April 2017; Accepted: 27 April 2018

\begin{abstract}
Abstrak
Tujuan dari penelitian ini untuk mengetahui peningkatan kemampuan komunikasi dan disposisi mahasiswa melalui pembelajaran diskursus multi representasi (DMR). Metode yang digunakan dalam penelitian adalah metode kuasi eksperimen dengan desain penelitian pretset-posttest control group design. Populasi yang dipilih dalam penelitian adalah seluruh dari mahasiswa pendidikan matematika IKIP Siliwangi yang mengikuti mata kuliah metode pembelajaran matematika sekolah SD pada semester ganjil Tahun Ajaran 2016/2017 yang terdiri dari 3 kelas, yaitu: A1, A2 dan A3. Sementara, Sampel penelitian yang dipilih terdiri dari 2 kelas yaitu kelas A2 sebagai kelas kontrol sebanyak 35 orang mahasiswa dan kelas A1 merupakan kelas eksperimen sebanyak dari 36 orang mahasiswa. Analisis data digunakan dalam pengolahan hasil gain pada kemampuan mahasiswa mata kuliah metode pembelajaran matematika sekolah SD. Sedangkan analisis skala disposisi matematis mahasiswa menggunakan Microsoft Excel 2010. Untuk memperoleh hasil data penelitian menggunakan instrumen berupa tes uraian dan skala disposisi. Analisis penelitian menggunakan uji perbedaan rata-rata Mann Whitney. Hasil penelitian menunjukkan bahwa: (1) Pencapaian dan peningkatan kemampuan komunikasi matematis yang mendapat pembelajaran DMR lebih baik daripada mahasiswa yang mendapat pembelajaran konvensional; dan (2) Disposisi matematis mahasiswa yang pembelajarannya menggunakan DMR lebih baik daripada mahasiswa dengan pembelajaran yang menggunakan pendekatan konvensional.
\end{abstract}

Kata Kunci: pembelajaran DMR, disposisi, komunikasi matematis

\section{Learning multi discourse representation to enhance students communication and their mathematical disposition}

\begin{abstract}
This study aims to determine the improvement of students' mathematical communication and dispositions ability through multi-representation discourse (DMR) learning. This research method is quasi-experimental with the design of pretset-posttest control group. The population is all students of mathematics education STKIP Siliwangi Bandung attending the course subject of Metode Pembelajaran Matematika SD (Elementary Mathematics Learning Method) in the first semester of 2016/2017 academic year consisting of three classes, namely: A1, A2 and A3. The samples are selected from two classes; $A 2$ as the control group consisting of 35 students and A1 as the experimental group consisting of 36 students.. Data analysis is performed to find out the gain from the results of students' ability test in the subject of Metode Pembelajaran Matematika SD; while the students' mathematical disposition scale analysis is conducted by using Microsoft Excel 2010. To obtain research data, the instruments of description test and disposition scale are used. The analysis of research uses the Mann Whitney's mean differences test. The results show that: (1) the achievement and improvement of communication ability of the students' receiving DMR learning are better than those who receive conventional learning; and (2) Mathematical disposition of students with DMR learning is better than those with the conventional approach.
\end{abstract}

Keywords: DMR learning, disposition, mathematical communication

How to Cite: Purwasih, R., \& Bernad, M. (2018). Pembelajaran diskursus multi representasi terhadap peningkatan kemampuan komunikasi dan disposisi matematis mahasiswa. Jurnal Riset Pendidikan Matematika, 5(1), 43-52. doi:http://dx.doi.org/10.21831/jrpm.v5i1.13589

Permalink/DOI:http://dx.doi.org/10.21831/jrpm.v5i1.13589 


\title{
Jurnal Riset Pendidikan Matematika, 5 (1), 2018 - 44
}

\author{
Ratni Purwasih, Martin Bernad
}

\section{PENDAHULUAN}

Matematika memiliki peranan penting dalam kehidupan manusia. Melalui pembelajaran matematika manusia mampu menggunakan istilah dan simbol yang cermat dan mudah dipahami. Seperti yang diungkapkan Ruseffendi (2006, p. 261) bahwa matematika sebagai bahasa simbol dipahami orang dengan tepat kita harus menggunakan simbol dan istilah yang cermat yang disepakati secara bersama.

Matematika bukan hanya meliputi hitungan semata namun salah satu bentuk ekpresi ungkapan yang penuh makna secara tulisan maupun lisan. Kemampuan komunikasi matematis merupakan kemampuan mahasiswa yang harus di miliki untuk mampu mengungkapkan ide-ide secara lisan maupun tulisan. Menurut Greenes \& Schulman (Untayana \& Harta, 2016) komunikasi matematis adalah kemampuan untuk: (1) menyatakan ide matematika melalui ucapan, tulisan, demonstrasi dan melukiskan secara visual dalam tipe yang berbeda; (2) memahami, menafsirkan dan menilai ide yang disajikan dalam tulisan, lisan atau dalam bentuk visual; (3) menafsirkan dan menghubungkan bermacammacam representasi ide dan hubungannya.Van de Walle (Khamid \& Santosa, 2016, p. 114) menyatakan bahwa komunikasi merupakan standar pokok yang memiliki arti penting dalam berbicara, menulis, menggambarkan dan menjelaskan ide-ide matematika. Belajar berkomunikasi dalam matematika dapat mengembangkan interaksi dan eksplorasi ide-ide di dalam kelas sebagai mahasiswa yang belajar aktif dalam lingkungan verbal.

Menurut Ontario Ministry of Education's (Zaini \& Marsigit, 2014) bahwa berkomunikasi matematis adalah menyampaikan makna melalui lisan, ditulis, dan bentuk visual (misalnya, memberikan penjelasan alasan atau pembenaran hasil secara lisan atau tertulis; mengkomunikasikan ide-ide matematika dan solusi secara tertulis, dengan menggunakan angka dan simbol aljabar, dan secara visual, menggunakan gambar, diagram, grafik, tabel, grafik, dan materi konkret). Menurut LAOCE (Hidayati, 2016), terdapat beragam bentuk komunikasi matematis, misalnya: (1) merefleksi ide-ide matematika; (2) Menggunakan simbol matematika dalam kehidupan sehari-hari (3) menstimulus ide matematika dan membuat argumen (conjecture) dan membuat argumen yang meyakinkan; (4) menggunakan keterampilan. Berdasarkan uraian tersebut, adapun indikator dari kemampuan komuni- kasi matematis yang digunakan yaitu: (1) mengorganisasi dan mengkonsolidasi pemikiran matematika mereka melalui komunikasi; (2) menyampaikan makna melalui lisan, ditulis, dan bentuk visual; (3) menggunakan keterampilan memvisualisasikan dan mengevaluasi ide-ide matematika.

Melalui aktivitas belajar mengajar di kelas, siswa dikembangkan kemampuan komunikasi matematis untuk menunjang prestasi belajar dan pemahaman terhadap konsep materi matematika. Melalui proses belajar ini, siswa dilatih dan distimulus kemampuan afektifnya. Salah satu kemampuan afektif yang diharapkan berkembang adalah disposisi matematis. Polking (Hendriana, 2012) menyatakan disposisi matematis meliputi: (1) rasa percaya diri dalam menggunakan matematika, memecahkan permasalahan, mengkomunikasikan gagasan; (2) fleksibilitas dalam menyelidiki gagasan matematis dan berusaha mencari metoda alternatif dalam memecahkan permasalahan; (3) tekun mengerjakan tugas matematika; (4) mempunyai minat, keingintahuan (curiosity), dan daya temu dalam melakukan pekerjaan matematika; (5) kecenderungan untuk memonitor dan merefleksikan performancedan penalaran mereka sendiri; (6) menilai aplikasi matematika ke situasi lain yang timbul dalam matematika dan pengalaman sehari-hari; (7) penghargaan (appreciation) peran matematika dalam kultur dan nilai, baik matematika sebagai alat, maupun matematika sebagai bahasa.

NCTM (Kusmaryono \& Dwijanto, 2016, p. 20) bahwa Pada pembelajaran matematika, disposisi merupakan salah satu komponen yang sangat penting bagi siswa (mahasiswa) karena Mahasiswa dibiasakan mendapatkan persoalanpersoalan yang memerlukan sikap postif, percaya diri, mandiri dan tangguh untuk menyelesaikannya. Menurut Kilpatric, Findel, \& Swaford (Kusmaryono \& Dwijanto, 2016) dis-posisi dapat didefinisikan sebagai suatu kecen-derungan siswa atau mahasiswa secara individu dalam memandang matematik secara positif atau negatif. Tanpa disposisi matematis yang baik maka siswa tidak dapat mencapai kompetensi atau kecakapan matematik sesuai harapan. Hal didukung oleh suatu pembelajaran yang inovatif yaitu pembelajaran diskursus multi representasi agar tercipta suasana belajar kon-dusif dan membantu kompetensi serta tujuan pembelajaran tercapai secara optimal. Oleh karena itu, erat kaitan antara disposisi matematis dengan pembelajaran pada saat berlangsung di kelas yang 
mengimplementasikan diskursus multi representasi. Pembelajaran diskursus multi representasi mampu meningkatkan kemampuan komunikasi dan ranah afektif mahasiswa yaitu disposisi matematis. Oleh karena itu, setting pembelajaran mata kuliah metode pembelajaran matematika SD mahasiswa dikondisikan sede-mikian rupa agar terbiasa untuk memberikan argumen setiap jawabannya serta memberikan tanggapan atas jawaban yang diberikan oleh orang lain. Hal inilah melatih kemampuan mahasiswa untuk berani dan penuh percaya diriberbicara mengungkapkan argumen dan solusi permasalahan. Pengembangan kemampuan komunikasi ini sangat diperlukan dalam rangka implementasi metode pembelajaran matematika sekolah SD di berbagai situasi dan kondisi. Sedangkan sikap mengaplikasikan matematika ke situasi lain dan bergairah serta serius terhadap matematika merupakan bagian dari disposisi matematis. Oleh karena itu, perlu suatu upaya untuk meningkatkan kemampuan komunikasi dan disposisi matematis mahasiswa dalam bentuk pembelajaran oleh dosen. Pembelajaran yang dimaksud adalah pembelajaran diskursus multi representasi yang selanjutnya di singkat DMR. Menurut Hudiono (2012) diskursus multi representasi adalah suatu pembelajaran yang menekankan pada pemanfaatan multi representasi dalam setting kelas berbentuk diskursus. Pembelajaran DMR ini memberikan kesempatan kepada mahasiswa untuk berusaha memahami permasalahan dan dosen mengarahkan dalam mengkomunikasikan ide-idenya dalam diskursus. Hal ini sejalan dengan Suherman (Purwasih, 2013) bahwa pembelajaran DMR merupakan salah satu pembelajaran matematika yang berorentasi kepada mahasiswa.

Setting pembelajaran di kelas menekankan pada aktivitas diskursus yaitu penggunaan suatu tugas yang memotivasi mahasiswa untuk memecahkan masalah yang disajikan melalui tugas, lembar kerja dan latihan bersama-sama secara berkelompok. Menurut Hudiono (Purwasih, 2013) mengatakan bahwa tahapantahapan pembelajaarn diskursus multi representasi meliputi persiapan, pendahuluan, pengembangan. Dalam DMR mahasiswa akan terpacu untuk melakukan aktivitas bertanya, berpendapat, menulis maupun berbicara multi arah untuk sampai pada kemampuan berkomunikasi matematis yang diharapkan.

Menurut Hudiono (Purwasih, 2013) pembelajaran matematika dengan model DMR meliputi: (1) intervensi, harapan pendidik dalam diskusi di kelas dapat berkembang kemampuan komunikasi matematis yang dimiliki mahasiswa yang mengantarkan pada pemahaman materi kuliah yang sedang dipelajari; (2) pendekatan dosen, pendekatan langsung mengarahkan mahasiswa presentasi dan memberikan jawaban terarah. Sedangkan pendekatan tidak langsung menstimulus mahasiswa melalui pertanyaan, merangkum hasil diskusi dan pemecahan masalah; (3) pengambilan keputusan, proses pembelajaran dalam diskursus dapat berjalan optimal melalui intervensi dosen. Dosen harus mampu menentukan strategi aman yang tepat dalam proses pembelajaarn. Untuk mengatasi pemasalahan tersebut, dosen memerlukan sikap yang teguh dalam pengambilan keputusan; (4) setting pembelajaran, dalam pelaksanaan pem-belajaarn di kelas melalui DMR ini terdapat aturan yang jelas tentang setting pembelajaarn yang akan berlangsung.

Pembelajaran DMR ini memberikan ruang gerak aktif untuk mengembangkan ke-mampuan komunikasi matematis mahasiswa melalui langkah-langkah diskursus yang meli-batkan peran mahasiswa untuk berargumen ter-hadap permasalahan matematika. Selain itu, mahasiswa termotivasi dan giat belajar untuk mengapliaksikan matematika terhadap lingkungan sehari-hari. Hal inilah salah satu bagian terpenting disposisi matematis yang muncul saat pembelajaran berlangsung. Melalui pembelajaran DMR ini diharapkan kemampuan komunikasi dan disposisi matematis mahasiswa dapat lebih baik dan meningkat sesuai harapan.

Manfaat penelitian ini adalahmahasiswa mengetahui tingkat kemampuan komunikasi dan disposisi matematis dalam belajar mata kuliah metode pembelajaran amtematika SD,mahasiswa lebih termotivasi untuk belajar, dapat mengetahui kondisi individu mahasiswa sehingga dosen mengetahui bagian materi mana yang belum dikuasai mahasiswa, sebagai masukan dalam pembaruan proses pembelajaran dengan pembelajaaran DMR untuk meningkatkan prestasi belajar. Berdasarkan kajian teori dan penelitian yang relevan diharapkan pembelajaran dengan pembelajaran diskursus multi representasi dapat meningkatkan kemampuan komunikasi dan disposisi matematis mahasiswa.

\section{METODE}

Metode yang digunakan dalam penelitian adalah metode kuasi eksperimen. Dalam penelitian ini ada dua kelas yang dibandingkan dengan 
memberikan perlakuan yang berbeda. Dengan desain penelitian sebagai berikut:

$\begin{array}{lll}\mathrm{O} & \mathrm{X} & \mathrm{O} \\ \mathrm{O} & & \mathrm{O}\end{array}$

Keterangan:

A $=$ Pengelompokkan subjek tidak acak kelas

$\mathrm{O}=$ Pretest Posttest

$\mathrm{X}=$ Pembelajaran menggunakan DMR

Penelitian ini dilaksanakan di STKIP Siliwangi Bandung pada semester ganjil tahun pelajaran 2016/2017 yang dimulai pada bulan Oktober 2016 sampai Desember yang mengikuti mata kuliah metode pembelajaran matematika sekolah $\mathrm{SD}$, yang terdiri dari 3 kelas, yaitu: A1, A2 dan A3. Sampel dalam penelitian ini adalah kelas A2 dengan 35 mahasiswa dan kelas A1 dengan 36 mahasiswa yang ditentukan dengan purpose random sampling. Kelas eksperimen (kelas A2) memperoleh penerapan model pembelajaran DMR dan kelas kontrol (kelas A1) memperoleh penerapan model pembelajaran konvensional.

\section{Prosedur}

Penelitian ini dilakukan dalam tiga tahap, yaitu persiapan dan pelaksanaan penelitian, serta penulisan laporan.

\section{Intrumen, dan Teknik Pengumpulan Data}

Instrumen yang digunakan dalam penelitian adalah tes kemampuan komunikasi matematis (Pretest dan Posttest) dalam bentuk essay untuk mengetahui kemampuan komunikasi matematis dan skala disposisi matematis disusun berdasarkan indikator-indikator variabel yang merupakan ciri-ciri prilaku yang hendak diteliti dan berisi pertanyaan-pertanyaan yang harus dijawab dengan pilihan yang sesuai dengan individu tersebut. Analisis hasil dari data disposisi matematis dilakukan dengan menggunakan model Likert termodifikasi. Format skoring skala disposisi matematis disajikan pada Tabel 1.

Tabel 1. Format Skoring Skala disposisi Matematis

\begin{tabular}{ccc}
\hline $\begin{array}{c}\text { Pilihan } \\
\text { jawaban }\end{array}$ & $\begin{array}{c}\text { Favourable } \\
\text { (Positif) }\end{array}$ & $\begin{array}{c}\text { Unfavourable } \\
\text { (Negatif) }\end{array}$ \\
\hline SS & 4 & 1 \\
S & 3 & 2 \\
TS & 2 & 3 \\
STS & 1 & 4 \\
\hline
\end{tabular}

\section{Teknik Analisis Data}

Tahap-tahapan pengolahan data hasil penelitian meliputi: (1) uji normalitas digunakan untuk melihat data tes awal (pretest) dan tes akhir (posttest) berdistribusi normal atau tidak. Uji yang digunakan adalah uji Shapiro-Wilk; (2) uji Homogenitas dilakukan untuk mengetahui kesamaan varians (homogenitas) antara kelas eksperimen dan kelas kontrol. Uji ini disebut dengan Uji Homogenitas Varians dengan menggunakan Uji F-test; (3) uji perbeda-an dua ratarata untuk mengetahui adanya perbedaan dua rata-rata kemampuan komunikasi matematis antara dua kelas. Uji hipotesis ini dengan menggunakan uji t (two tailed); (4) uji gain ternormalisasi untuk mengetahui seberapa besar peningkatan kemampuan komunikasi matematis mahasiswa; (5) melakukan analisis angket skala sikap dengan menghitung persentase jawaban mahasiswa. Skor setiap indikator merupakan jumlah bobot nilai tiap jawaban mahasiswa dalam indikator tersebut.

Semua pengolahan data menggunakan SPSS 17.0 dan microsoft excel 2010. Adapun rumus gain ternormalisasi dari Hake (Putra \& Purwasih, 2016), sebagai berikut:

\section{$\mathrm{g}=\frac{\text { skor tes terakhir-skor tes awal }}{\text { skor maksimum ideal-skor tes awal }}$}

Tingkat perolehan skor gain ternormalisasi dikelompokkan ke dalam tiga kategori yaitu:

Tabel 2. Kriteria Indeks Gain

\begin{tabular}{cc}
\hline Gain & Kriteria \\
\hline $\mathrm{g}>0,7$ & Tinggi \\
$0,3<\mathrm{g} \leq 0,7$ & Sedang \\
$\mathrm{g} \leq 0,3$ & Rendah \\
\hline
\end{tabular}

Tabel 3. Kriteria Interpretasi Skor Skala Disposisi Matematis Mahasiswa

\begin{tabular}{cc}
\hline Nilai & Kriteria \\
\hline $0 \%-30 \%$ & Sangat lemah \\
$31 \%-50 \%$ & Lemah \\
$51 \%-70 \%$ & Cukup \\
\hline $71 \%-85 \%$ & Kuat \\
\hline $86 \%-100 \%$ & Sangat kuat \\
\hline
\end{tabular}

Untuk mendapatkan gambaran kualitas disposisi matematis mahasiswa dalam perkuliahan metode pembelajaran matematika SD dilakukan perhitungan rerata dan skor persentasi ter-hadap skor total. Instrumen skala disposisi matematis terdiri dari 21 item pernyataan positif dan 14 item pernyataan negatif. Adapun kriteria interpretasi skor disposisi matematis mahasisw 
adari modifikasi pendapat Riduwan (2010) adalah seperti pada Tabel 3 .

\section{HASIL DAN PEMBAHASAN}

Berdasarkan hasil skor pretest dan posttest pada aspek yang akan di ukur yaitu aspek kemampuan komunikasi matematis, diperoleh nilai minimum (X min), skor maksimun (X max), rerata, dan simpangan baku (s). Data disajikan pada Tabel 4.

Tabel 4. Statistika Deskriptif Pretest dan PosttestKemampuan Komunikasi Matematis

\begin{tabular}{ccccc}
\hline Nilai & \multicolumn{2}{c}{ Eksperimen } & \multicolumn{2}{c}{ Kontrol } \\
\hline & Pretestt & Posttest & Pretestt & Posttest \\
$\mathrm{N}$ & 36 & 36 & 35 & 35 \\
$\mathrm{X}_{\text {min }}$ & 4 & 14 & 3 & 8 \\
$\mathrm{X}_{\text {maks }}$ & 14 & 19 & 9 & 14 \\
$\overline{\boldsymbol{x}}$ & 6,96 & 16,84 & 6,42 & 12,11 \\
$\mathrm{~S}$ & 1,43 & 1,44 & 1,24 & 1,09 \\
$\%$ & 26,80 & 89,20 & 25,75 & 58,50 \\
\multicolumn{4}{c}{} & Skor Maksimum Ideal = 20 \\
\hline
\end{tabular}

Tabel 4 menunjukan bahwa rata-rata skor hasil pretest kelas dari kedua kelas tidak ada perbedaan. Hal ini menunjukan bahwa data pretest untuk kedua kelompok sampel tidak jauh berbeda dengan kualifikasi masing-masing kelompok dan sampel berada pada katagori kurang. Sedangkan hasil dari posttest menunjukan bahwa kelas eksperimen lebih unggul dibandingkan dengan kelas kontrol. Rata-rata kelas eksperimen sebesar 16,84 dari skor maksimum ideal lebih besar daripada kelas kontrol. Dari hasil pengamatan mengenai pencapaian kemampuan komunikasi matematis mahasiswa. Pengujian normalitas skor pretest dihitung dengan menggunakan program SPSS 17for windows dengan menggunakan uji Shapiro-Wilk. Hipotesis yang diuji pada masing-masing data pretest kemampuan komunikasi matematis pada kedua kelas tersebut, adalah:

Ho: sampel berdistribusi normal

Ha: sampel tidak berdistribusi normal

Kriteria pengujian, jika $\mathrm{P}$ value (sig.) $>\alpha$, maka Ho diterima dan jika $\mathrm{P}$ value (sig.) $<\alpha$, maka Ho ditolak, dengan taraf signifikan sebesar $\alpha=0,05$. Hasil uji normalitas dapat dilihat pada Tabel 5.

Berdasarkan Tabel 5, dapat diketahui bahwa nilai signifikansi berdasarkan uji ShapiroWilk untuk kemampuan komunikasi matematis pada kelas eksperimen dan kontrol, masingmasing kurang dari nilai $\alpha=0,05$. Ini berarti bahwa Ho ditolak dan Ha diterima. Jadi, data tersebut tidak berdistribusi normal. Untuk selanjutnya dilakukan uji Mann-Whitney untuk skor pretest kemampuan komunikasi pada kelas yang menggunakan pembelajaran DMR dan pembelajaran konvensional. Karena data tidak berdistribusi normal maka uji homogenitas varians tidak bisa dilakukan. Uji statistik berikutnya adalah dengan uji nonparametrik Mann-Whitney yang bertujuan untuk melihat uji perbedaan dua rata-rata skor pretest kemampuan komunikasi matematis antara kelas yang pembelajarannya DMR dan kelas dengan pembelajaran konvensional.

Tabel 5. Uji Normalitas Pretest pada Kedua Kelas

\begin{tabular}{cccc}
\hline \multirow{2}{*}{ Kelas } & \multicolumn{3}{c}{ Shapiro-Wilk } \\
\cline { 2 - 4 } & Statistic. & Df & Sig. \\
\hline Eksperimen & 0,883 & 36 & 0,028 \\
Kontrol & 0,874 & 35 & 0,003 \\
\hline
\end{tabular}

Karena nilai signifikan kedua data $<\alpha$, maka Ho ditolak dan Ha diterima dengan tingkat signifikansi $\alpha=0,05$, dapat disimpulkan bahwa terdapat perbedaan rerata skor pretest antara kemampuan awakomunikasi matematis kelas yang menggunakan pembelajaran DMR dan pembelajaran konvensional.

Hasil perhitungan uji Mann-Whitney kemampuan komunikasi matematis diperlihatkan pada Tabel 6.

Tabel 6. Uji Mann-Whitney Skor

PretestKemampuan Komunikasi Matematis

\begin{tabular}{cc}
\hline Mann Whitney & Sig. (2tailed) \\
\hline 353,000 & 0,902 \\
\hline
\end{tabular}

Tabel 6 menunjukan bahwa nilai sig. (2pihak $)=0,902$, maka nilai sig.(2-pihak) yang diperoleh lebih dari $\alpha$, sehingga Ho diterima. Jadi, dapat disimpulkan bahwa kedua kelas tidak terdapat perbedaan kemampuan awal komunikasi matematis di antara kedua kelas tersebut.Pengujian normalitas skor posttest dihitung dengan menggunakan program SPSS 17. Hasil uji normalitas dapat dilihat pada Tabel 7:

Tabel 7. Uji Normalitas Skor Posttest Kemampuan Komunikasi Matematis

\begin{tabular}{cccc}
\hline \multirow{2}{*}{ Kelas } & \multicolumn{3}{c}{ Shapiro-Wilk } \\
\cline { 2 - 4 } & Statistic. & Df & Sig. \\
\hline Eksperimen & 0,598 & 36 & 0,000 \\
Kontrol & 0,789 & 35 & 0,002 \\
\hline
\end{tabular}

Berdasarkan Tabel 7, dapat diketahui bahwa nilai signifikansi berdasarkan uji ShapiroWilk untuk kemampuan komunikasi matematis pada kedua kelas kurang dari nilai $\alpha$. Ini berarti 
bahwa Ho ditolak dan Ha diterima, berarti sampel dari kedua data tersebut tidak berdistribusi normal. dilanjutnya uji Mann-Whitney.

Hasil perhitungan uji Mann-Whitney untuk uji rerata skor posttest kemampuan komunikasi matematis diperlihatkan pada Tabel 8 .

Tabel 8. Uji Mann-Whitney Skor Posttest Kemampuan Komunikasi Matematis

\begin{tabular}{cc}
\hline Mann Whitney & Sig. (2tailed) \\
\hline 268,300 & 0,065 \\
\hline
\end{tabular}

Tabel 8 memperlihatkan bahwa nilai signifikan > 0,05. Dan karena uji Mann-Whitney yang digunakan untuk menguji perbedaan rerata skor posttest kemampuan komunikasi matematis dari kedua kelas ini merupakan uji satu pihak. Hal ini, sesuai Uyanto (Rohmah, 2013), nilai signifikan untuk satu pihak adalah $\frac{1}{2} \times$ signifikan dari 2 pihak. Adapun kriteria pengujiannya adalah Ho diterima jika nilai sig. (1-pihak) $>\alpha$, dan yang lainnya Ha ditolak. Sedangkan jika nilai sig.(1pihak) $<\alpha$, maka Ho ditolak, dan yang lainnya $\mathrm{Ha}$ diterima dengan tingkat signifikansi $\alpha=0,05$. Karena nilai sig. $(2$-pihak $)=0,065$, maka nilai sig. (1-pihak) $=\frac{1}{2} \times 0,065=0,0325$. Nilai sig. $(1-$ pihak) yang diperoleh kurang daria, sehingga Ho ditolak. Artinya bahwa pencapaian kemampuan komunikasi matematis mahasiswa yang pembelajarannya menggunakan pembelajaran DMR lebih baik dibandingkan dengan mahasiswa yang menggunakan pembelajaran konvensional. Setelah uji Mann Whitney dilanjukan uji gain ternormalisasi untuk menguji hipotesis. Adapun hipotesis yang ingin di uji yang berkenaan dengan peningkatan kemampuan komunikasi matematis mahasiswa dari kedua kelas dimana masaingmasing kelas yang pembelajarannya menggunakan DMR lebih baik daripada pembelajaran konvensional.

Analisis gain ternormalisasi ini dimaksudkan untuk melihat peningkatan kemampuan komunikasi matematis mahasiswa yang pembelajarannya menggunakan DMR dan pembelajaran pembelajaran konvensional. Data gain ternormalisasi berasal dari selisih skor posttest dengan skor pretest dari masing-masing skor tes kemampuan komunikasi matematis mahasiswa dibagi dengan selisih antara skor maksimum ideal dengan skor pretest. Tabel 9 menyajikan deskriptif gain ternormalisasi kemampuan komunikasi matematis dengan menggunakan program SPSS 17 for windows:
Tabel 9. Statistik Deskriptif Gain Ternormalisasi Kemampuan Komunikasi Matematis Mahasiswa

\begin{tabular}{ccc}
\hline Data Gain & Eksperimen & Kontrol \\
\hline $\mathrm{N}$ & 36 & 35 \\
$\mathrm{X}_{\min }$ & 0,13 & 0,09 \\
$\mathrm{X}_{\text {maks }}$ & 0,92 & 0,43 \\
$\overline{\boldsymbol{x}}$ & 0,65 & 0,34 \\
$\mathrm{~S}$ & 1,75 & 0,82 \\
$\%$ & $31 \%$ & 19,79 \\
\hline
\end{tabular}

Berdasarkan Tabel 9, menunjukan bahwa kualifikasi rerata gain kelas kontrol memiliki nilai sebesar 0,34 , sedangkan untuk kelas eksperimen memiliki nilai rerata gain sebesar sebesar 0,65 . Selanjutnya pengujian normalitas skor gain ternormalisasi dihitung dengan menggunakan program SPSS 17 for windows pada uji ShapiroWilk. Hipotesis yang diuji pada data gain ternormalisasi kemampuan komunikasi matematis mahasiswa pada kelas eksperimen maupun kelas kontrol adalah:

Ho: sampel berdistribusi normal

Ha: sampel tidak berdistribusi normal

Kriteria pengujian, jika $\mathrm{P}$ value (sig.) > 0,05 , maka Ho diterima dan jika $\mathrm{P}$ value (sig.)< 0,05 , maka Ho ditolak. Hasil uji normalitas skor gain ternormalisasi dapat dilihat pada Tabel 10.

Tabel 10. Hasil Uji Normalitas Data Gain Kemampuan Komunikasi Matematis

\begin{tabular}{ccc}
\hline $\begin{array}{c}\text { Data Gain } \\
\text { Kolmogorov- } \\
\text { Smirnov }\end{array}$ & Eksperimen & Kontrol \\
\hline Stat. & 0,202 & 0,161 \\
Df & 36 & 35 \\
Sig. & 0,830 & 0,010 \\
& $\begin{array}{c}\text { Sampel berasal } \\
\text { dari populasi }\end{array}$ & $\begin{array}{c}\text { Sampel berasal } \\
\text { dari populasi }\end{array}$ \\
Kesimpulan & yang & yang tidak \\
& berdistribusi & berdistribusi \\
& normal & normal \\
\hline
\end{tabular}

Berdasarkan Tabel 10, uji normalitas skor gain ternormalisasi kemampuan komunikasi matematis mahasiswa yang pembelajarannya menggunakan DMR dengan Uji Shapiro-Wilk diperoleh nilai Sig. lebih dari nilai 0,05. Tetapi, untuk kemampuan komunikasi matematis yang pembelajaraanya konvensional nilai Sig. kurang dari nilai 0,05 . Ini berarti untuk uji homogenitas menggunakan uji nonparametrik Mann-Whitney.

Selanjutnya dilakukan uji Mann-Whitney untuk gain ternormalisasi kemampuan komunikasi matematis mahasiswa. Adapun hipotesis yang diuji adalah peningkatan kemampuan komunikas matematis mahasiswa yang pembel- 
ajarannya menggunakan DMR lebih baik dibandingkan dengan mahasiswa yang meggunakan pembelajaran konvensional. Rumusan hipotesis statistik yang diuji untuk menguji hipotesis yang diajukan adalah:

$\mathrm{H}_{0}: \mu_{1} \leq \mu_{2}$

$\mathrm{H}_{\mathrm{a}}: \mu_{1}>\mu_{2}$

$\mathrm{H}_{0}: \mu_{1} \leq \mu_{2}$ (peningkatan kemampuan komunikasi matematis mahasiswa yang pembelajarannya menggunakan model DMR tidak lebih baik daripada yang menggunakan pembelajaran konvensional).

$\mathrm{H}_{1}: \mu_{1}>\mu_{2}$ (peningkatan kemampuan komunikasi matematis mahasiswa yang pembelajarannya menggunakan model DMR lebih baik daripada yang menggunakan pembelajaran konvensional).

Hasil dari Uji Mann Whitney gain kemampuan komunikasi matematis dapat dilihat pada Tabel 11.

Tabel 11. Uji Mann-Whitney Gain Ternormalisasi Kemampuan Komunikasi Matematis

\begin{tabular}{cccc}
\hline \multicolumn{3}{c}{ Mann Whitney } & \multirow{2}{*}{ Keterangan } \\
\cline { 1 - 3 } $\mathbf{Z}$ & Sig.(2-tailed) & Df & \\
\hline $\mathbf{- 5 , 0 1 7}$ & 0,000 & 70 & $\mathrm{H}_{0}$ Ditolak \\
\hline
\end{tabular}

Berdasarkan Tabel 11 menunjukan nilai signifikan dari kedua kelas yang diperoleh kurang dari 0,05 , sehingga Ho ditolak. Artinya peningkatan kemampuan komunikasi matematis mahasiswa yang pembelajarannya menggunakan DMR lebih baik dibandingkan dengan mahasiswa yang menggunakan pembelajaran konvensional.

Pembelajaran DMR mahasiswa dituntut belajar mengemukakan masalah yang relevan sesuai materi kuliah yang sedang diajarkan. Kondisi belajar diksursus membantu suasana kelas lebih aktif dan pembelajaran multi arah.

Data pretest yang diperoleh merupakan pijakan awal dalam menafsirkan kemampuan awal komunikasi dan disposisi matematis mahasiswa. Kemudian data posttest bagian terpenting untuk informasi capaian kemampuan komunikasi matematis setelah pembelajaran DMR di implementasikan dalam kehidupan sehari-hari.

Pembelajaran DMR membantu mahasiswa lebih aktif dan paham terhadap materi kuliah sehingga mereka termotivasi lebih baik kemampuan berkomunikasinya. Hal tersebut membuat mahasiswa memiliki kepercayaan diri dan motivasi serta giat untuk bisa menyelesaikan perma- salahan yang dihadapinya. Pembelajaran DMR memberikan kemajuan bagi mahasiswa untuk mengembangkan kemampuan komunikasi matematisnya. Hal ini sejalan dengan Feldhaus (2014) mengatakan bahwa pengalaman seseorang individu akan membentuk disposisi matematis seseorang. Hal ini cukup beralasan karena apabila pembelajaran DMR dilaksanakan dengan baik akan membuat mahasiswa aktif dalam suasana belajar sehingga kemampuan komunikasi matematis akan lebih terasah berkembang dengan baik. Untuk lebih jelas hasil dari deskriptif statistik disposisi matematis mahasiswa kelas eksperimen dan kontrol. terlihat pada Tabel 12 dan Tabel 13.

Tabel 12. Deskriptif Statistik Disposisi

Matematis Mahasiswa Kelas Eksperimen

\begin{tabular}{lccc}
\hline \multirow{2}{*}{ Indikator } & \multicolumn{2}{c}{ Total } & Kriteria \\
\cline { 2 - 4 } & $\overline{\boldsymbol{x}}$ & \% & \\
\hline $\begin{array}{l}\text { Fleksibel, tekun } \\
\text { mengerjakan tugas }\end{array}$ & 12,9 & 64,9 & cukup \\
matematika & & & \\
$\begin{array}{l}\text { Rasa percaya diri } \\
\text { Minat, rasa ingin tahu }\end{array}$ & 32,5 & 73,7 & kuat \\
$\begin{array}{l}\text { Mengapresiasi peran } \\
\text { matematika dalam kultur }\end{array}$ & 17,5 & 67,5 & cukup \\
dan nilai matematika & & & \\
$\begin{array}{l}\text { sebagai alat dan bahasa } \\
\text { Cenderung memonitor }\end{array}$ & 8,33 & 69,8 & cukup \\
$\begin{array}{l}\text { diri sendiri } \\
\text { Mengaplikasikan }\end{array}$ & 15,5 & 76,6 & kuat \\
$\begin{array}{l}\text { matematika ke situasi } \\
\text { lain }\end{array}$ & & & \\
\multicolumn{1}{c}{ Jumlah Total } & 100,2 & 71,6 & kuat \\
\hline
\end{tabular}

Tabel 13. Deskriptif Statistik Disposisi Matematis Mahasiswa Kelas Kontrol

\begin{tabular}{lccc}
\hline \multirow{2}{*}{\multicolumn{1}{c}{ Indikator }} & \multicolumn{2}{c}{ Total } & Kriteria \\
\cline { 2 - 4 } & $\overline{\boldsymbol{x}}$ & \% & \\
\hline $\begin{array}{l}\text { Fleksibel, tekun } \\
\text { mengerjakan tugas }\end{array}$ & 11,9 & 58,4 & Cukup \\
matematika & & & \\
$\begin{array}{l}\text { Rasa percaya diri } \\
\text { Minat, rasa ingin tahu }\end{array}$ & 32,7 & 73,4 & Kuat \\
$\begin{array}{l}\text { Mengapresiasi peran } \\
\text { matematika dalam kultur }\end{array}$ & 17,2 & 71,8 & Kuat \\
$\begin{array}{l}\text { dan nilai matematika } \\
\text { sebagai alat dan bahasa }\end{array}$ & & & \\
$\begin{array}{l}\text { Cenderung memonitor diri } \\
\text { sendiri }\end{array}$ & 8,7 & 73,9 & Kuat \\
$\begin{array}{l}\text { Mengaplikasikan } \\
\text { matematika ke situasi lain }\end{array}$ & 14,6 & 74,1 & Kuat \\
Jumlah Total & 98,2 & 70,3 & Cukup \\
\hline
\end{tabular}

Tabel 12 memperlihatkan bahwa indikator dari disposisi matematis mahasiswa kelas eksperimen termuat ke dalam kategori cukup dan kuat. Presentase yang paling besar terdapat pada indi- 
kator mengaplikasikan matematika ke situasi lain sebesar 76,6\%. Indikator ini memberikan gambaran bahwa hasil dari pembelajaran DMR ini mampu meningkatkan kemampuan disposisi matematis mahasiswa lebih baik dari sebelumnya. Sedangkan kriteria yang memiliki presentase paling kecil dan kategori cukup yaitu fleksibel, tekun mengerjakan tugas matematika.

Pengujian normalitas skor posttest skor disposisi matematis dihitung dengan menggunakan program SPSS 17 for windows dengan menggunakan uji Shapiro-Wilk. Hipotesis yang diuji pada masing-masing data posttest disposisi matematis pada pada kedua kelas yang diujikan sebagai berikut:

Ho: sampel berdistribusi normal

Ha: sampel tidak berdistribusi normal

Kriteria pengujian, jika $\mathrm{P}$ value (sig.) >, maka Ho diterima dan jika $\mathrm{P}$ value (sig.) <, maka Ho ditolak, dengan taraf signifikan sebesar $=$ 0,05 . Hasil uji normalitas dapat dilihat pada Tabel 14.

Tabel 14. Uji Normalitas Skor Posttest Disposisi Matematis

\begin{tabular}{cccc}
\hline \multirow{2}{*}{ Kelas } & \multicolumn{3}{c}{ Shapiro-Wilk } \\
\cline { 2 - 4 } & Statistic. & Df & Sig. \\
\hline Eksperimen & 0,899 & 36 & 0,016 \\
Kontrol & 0,789 & 35 & 0,004 \\
\hline
\end{tabular}

Berdasarkan Tabel 14, uji normalitas skor disposisi matematis mahasiswa yang pembelajarannya DMR dan konvensional dengan Uji Shapiro-Wilk diperoleh nilai Sig. kurang dari nilai $\alpha=0,05$ yang berarti $\mathrm{Ho}$ ditolak dan $\mathrm{Ha}$ diterima. Jadi, sampel berasal tidak berdistribusi normal. Langkah selanjutnya dilakukan Uji Mann-Whitney.

Uji nonparametrik Mann-Whitney yang bertujuan untuk melihat uji perbedaan dua ratarata skor disposisi matematisantara kelas yang pembelajarannya DMR dan kelas dengan pembelajaran konvensional. Adapun hipotesis yang diuji adalah mahasiswa di kelas eksperimen memiliki kemampuan disposisi matematis lebih baik dibandingkan dengan kemampuan disposisi mahasiswa di kelas kontrol. Adapun rumusan hipotesis statis-tik yang diuji untuk menguji hipotesis yang diajukan adalah:

$\mathrm{H}_{0}: \mu_{1} \leq \mu_{2}$

$\mathrm{H}_{\mathrm{a}}: \mu_{1}>\mu_{2}$

$\mathrm{H}_{0}: \mu_{1} \leq \mu_{2}$ (peningkatan disposisi matematis mahasiswa yang pembelajarannya menggunakan model DMR tidak lebih baik atau sama denganpembelajaranyang mengguna-kan konvensional)

$\mathrm{H}_{1}: \mu_{1}>\mu_{2}$ (peningkatan disposisi matematis mahasiswa yang pembelajarannya menggunakan model DMR lebih baik daripada yang menggunakan pembelajaran konvensional)

Hasil dari Uji Mann Whitney gain disposisi matematis dapat dilihat pada Tabel 15.

Tabel 15. Uji Mann-Whitney Gain

Ternormalisasi Disposisi Matematis

\begin{tabular}{cc}
\hline Mann Whitney & Sig. (2tailed) \\
\hline 308,00 & 0,052 \\
\hline
\end{tabular}

Tabel 15 memperlihatkan bahwa nilai signifikan dari 2 pihak kurang dari 0,05. Akan tetapi, uji Mann-Whitney yang digunakan untuk menguji perbedaan rerata skor disposisi matematik ini adalah uji satu pihak. Menurut Uyanto (Rohmah, 2013), nilai sig. (1-pihak) $=\frac{1}{2} \times$ sig. (2-pihak). Adapun kriteria pengujiannya adalah Ho diterima jika nilai sig. (1-pihak) $>\alpha$, dan yang lainnya $\mathrm{Ha}$ ditolak. Sedangkan jika nilai sig.(1-pihak) $<\alpha$, maka Ho ditolak, dan yang lainnya Ha diterima dengan tingkat signifikansi $\alpha=0,05$. Karena nilai sig. (2-pihak) $=0,052$, maka sig. $(1$ pihak $)=0,026$. Nilai sig.(1-pihak) yang diperoleh kurang dari $\alpha$, sehingga Ho ditolak. Artinya peningkatan disposisi matematis mahasiswa yang pembelajarannya menggunakan model DMR lebih baik daripada yang menggunakan pembelajaran konvensional.

Berdasarkan pengamatan penulis di lapangan bahwa pembelajaran dengan DMR memiliki kelebihan dalam meningkatkan kemampuan komunikasi mahasiwa, karena dalam pembelajaran DMR mendorong mahasiswa aktif berfikir, memberi kesempatan kepada mahasiswa untuk menanyakan hal-hal yang kurang jelas sehingga dosen dapat menjelaskan kem-bali. Perbedaan pendapat antara mahasiswa dapat dikompromikan atau diarahkan pada suatu diskusi. Pertanyaan yang diajukan dapat menarik dan memusatkan perhatian mahasiswa, dan cara meninjau kembali (review) materi kuliah sebelumnya serta mengembangkan keberanian dan keterampilan mahasiswa dalam menjawab dan mengemukakan pendapat.

Pada analisis disposisi matematis mahasiswa baik pada mahasiswa dengan pembelajaran DMR maupun dengan pembelajaran konvensional secara umum menunjukkan sikap positif yang baik. Akan tetapi, disposisi matematis mahasiswa yang menggunakan pembelajaran DMR masih lebih baik daripada mahasiswa yang meggunakan 


\section{Jurnal Riset Pendidikan Matematika, 5 (1), 2018 - 51}

Ratni Purwasih, Martin Bernad

pembelajaran konvensional karena menurut kategori disposisi matematis mahasiswa yang menggunakan pembelajaran DMR cenderung kuat. disposisi matematis mahasiswa yang paling tinggi menggunakan pembelajaran DMR adalah pada indikator yang mengaflikasikan matematika ke situasi lain. Hal ini cukup menggembirakan karena ternyata mahasiswa senang melatih kemampuan matematis seperti dengan berdiskusi dalam kelompok agar berhasil dalam belajarnya. Sedangkan sikap positif yang nilainya kecil terjadi pada indikator fleksibel dan tekun mengerjakan tugas matematika. Untuk disposisi matematis mahasiswa pada kelas dengan pembelajaran konvensional sikap positif yang paling besar pada rasa percaya diri. Sikap positif yang relatif kurang adalah pada indikator cenderung memonitor diri sendiri.

Berdasarkan skala pendapat mahasiswa, rata-rata secara keseluruhan pendapat mahasiswa tehadap pembelajaran matematika dengan DMR adalah memiliki kecenderungan yang positif. Pada saat proses pembelajaran berlangsung dengan menggunakan DMR, mahasiswa cenderung lebih aktif mengikuti diskusi dan berpartisipasi dalam mengungkapkan ide matematis secara lisan maupun tuliasan untuk menyelesaikan masalah yang ada. Setiap mahasiswa saling bekerja sama dan berani mengemukakan ide atau pendapatnya. Mahasiswa memiliki pandangan positif terhadap pembelajar DMR ini sehingga menstimulus mereka untuk berperan aktif dalam menyelesaikan permasalahan matematika di kelas. Mahasiswa tidak enggan dan ragu-ragu dalam melakukan aktifitas yang mengarah kepada berkomunikasi selama pembelajaran berlangsung yang dihadapi, mahasiswa berani dan percaya untuk mengungkapkan pendapatnya di depan kelas. Hal ini, mampu meningkatkan kemampuan kognitif mahasiswa dalam proses membangun dan merumuskan sendiri dari serangkaian kasus yang diberikan. Hal ini menurut dugaan peneliti disebabkan karena mahasiswa sudah mempunyai pemahaman dasar tentang materi metode pembelajaran sekolah SD sebelumnya, sehingga mahasiswa antusias terhadap konsep baru dalam belajar, dilengkapi dengan penerapan pembelajaran DMR membuat maha-siswa jadi lebih termotivasi dalam proses pembelajaran. Hal ini sejalan dengan penelitian (Rostika \& Junita, 2017) bahwa pembelajaran DMR ini memberikan keuntungan dan manfaat yaitu membuat suasana belajar lebih aktif, komunikatif, dan menumbuhkan rasa percaya diri.
Pada analisis skala pendapat mahasiswa menunjukkan bahwa sikap mahasiswa terhadap pembelajaran matematika bersifat positif. Artinya dengan adanya pembelajaran matematika dengan pembelajaran DMR memberikan warna baru dalam belajar. Mahasiswa merasa senang, dan nyaman dengan pembelajaarn DMR tersebut. Dari hasil perlakuan terhadap kelas yang menggunakan pembelajaran DMR terlihat proses pembelajaran yang aktif antara mahasiswa dengan mahasiswa maupun mahasiswa dengan dosen. Dosen menggunakan pendekatan secara langsung maupun tidak langsung pada saat kegiatan belajar mengajar di kelas. Hal ini bertujuan untuk memberikan pembelajaran yang mengarahkan untuk meningkatkan kemampuan komunikasi dan disposisi matematis mahasiswa. Hal ini sejalan dengan Hudiono (2012) bahwa pembelajaran diskursus multi representasi dapat mengembangkan kemampuan matematis salah satunya kemampuan komunikasi matematis. Berbeda dengan kelas yang pembelajarannya dengan cara konvensional. Pembelajaran konvensional membuat mahasiswa cenderung pasif dan diskusi satu arah. Dengan demikian untuk kelas yang menerima perlakuan pembelajaran DMR diharapkan kemampuan komunikasi dan disposisi matematis terccapai sesuai dengan tujuan penelitian.

\section{SIMPULAN}

Berdasarkan temuan dan pembahasan, penelitian ini dapat disimpulkan bahwa: (1) pencapaian dan peningkatan kemampuan komunikasi matematis mahasiswa yang pembelajarannya menggunakan pembelajaran DMR lebih baik daripada yang menggunakan pembelajaran konvensional; (2) disposisi matematis mahasiswa yang pembelajarannya menggunakan pembelajaran DMR lebih baik daripada yang menggunakan pembelajaran konvensional. Disposisi matematik kedua kelas tergolong sedang.

Berdasarkan temuan dalam penelitian saran-saran yang diajukan penulis meliputi: (1) pembelajaran DMR dapat dijadikan salah satu alternatif pembelajaran matematis di sekolah atau perguruan tinggi untuk meningkatkan kemampuan komunikasi dan disposisi matematis; (2) penerapan pembelajaran DMR yang lebih efektif hendaknya mempersiapkan saran belajar yang memadai, misalnya modul, LKM, atau buku sumber secara optimal sehingga kebutuhan mahasiswa akan imformasi terpenuhi. 


\section{DAFTAR PUSTAKA}

Feldhaus, C. A. (2014). How pre service elementary school teachers' mathematical dispositions are influenced by school mathematics. American International Journal of Contemporary Research, 4(6), 91-97.

Hendriana, H. (2012). Pembelajaran matematika humanis dengan metaphorical thinking untuk meningkatkan kepercayaan diri siswa. Infinity Journal, $1(1), 90$. https://doi.org/10.22460/infinity.v1i1.9

Hidayati, N. (2016). Meningkatkan kemampuan pemahaman dan penalaran serta disposisi matematis mahaisiswa melalui model pembelajaran metokognitif. MENDIDIK: Jurnal Kajian Pendidikan Dan Pengajaran, 2(2), 131-142.

Hudiono, B. (2012). Peran pembelajaran diskursus multi representasi terhadap pengembangan kemampuan matematika dan daya representasi pada siswa SLTP. Jurnal Cakrawala Kependidikan, 8(2).

Khamid, A., \& Santosa, R. H. (2016). Keefektifan pendekatan PBL dan CTL ditinjau dari komunikasi matematis dan motivasi belajar siswa SMP. PYTHAGORAS: Jurnal Pendidikan Matematika, 11(2), 111. https://doi.org/10.21831/pg.v11i2.10660

Kusmaryono, I., \& Dwijanto, D. (2016). Peranan representasi dan disposisi matematis siswa terhadap peningkatan mathematical power. JIPMat (Jurnal Ilmiah Pendidikan Matematika),

1(1). https://doi.org/10.26877/jipmat.v1i1.1089

Purwasih, R. (2013). Peningkatan kemampuan komunikasi matematis siswa SLTP melalui model pembelajaran diskursus multi representasi (DMR). Universitas Pendidikan Indonesia.

Putra, H. D., \& Purwasih, R. (2016).
Meningkatkan prestasi belajar dan keaktifan mahasiswa melalui project based learning. P2M STKIP Siliwangi, 2(2), 128-136. https://doi.org/10.22460/p2m.v2i2p128136.156

Riduwan, M. B. A. (2010). Metode dan teknik menyusun tesis. Bandung: Alfabeta.

Rohmah, M. S. (2013). Pendekatan brainstorming teknik round-robin untuk meningkatkan kemampuan penalaran, komunikasi matematis dan self-awareness siswa SMP. Universitas Pendidikan Indonesia.

Rostika, D., \& Junita, H. (2017). Peningkatan kemampuan pemecahan masalah siswa SD dalam pembelajaran matematika dengan model diskursus multy representation (DMR). EDUHUMANIORA: Jurnal Pendidikan Dasar, 9(1), 35-46. https://doi.org/10.17509/EH.V9I1.6176

Ruseffendi, E. T. (2006). Pengantar kepada membantu guru mengembangkan kompetensinya dalam pengajaran matematika untuk meningkatkan CBSA. Bandung: Tarsito.

Untayana, J. R., \& Harta, I. (2016). Pengembangan perangkat pembelajaran limit berbasis pendekatan saintifik berorientasi prestasi belajar dan kemampuan komunikasi matematika. Jurnal Riset Pendidikan Matematika, 3(1), 45. https://doi.org/10.21831/jrpm.v3i1.9683

Zaini, A., \& Marsigit, M. (2014). Perbandingan keefektifan pembelajaran matematika dengan pendekatan matematika realistik dan konvensional ditinjau dari kemampuan penalaran dan komunikasi matematik siswa. Jurnal Riset Pendidikan Matematika, $\quad 1(2), \quad 152$. https://doi.org/10.21831/jrpm.v1i2.2672 